\title{
NOTE
}

\section{Ovarian mycosis in the topsmelt Atherinops affinis*}

\author{
James T. Winstead, Douglas P. Middaugh, Lee A. Courtney \\ U.S. Environmental Protection Agency, Environmental Research Laboratory, Sabine Island, Gulf Breeze, Florida 32561, USA
}

ABSTRACT: An ovarian mycosis in a topsmelt Atherinops affinis (Ayres), collected from Elkhorn Slough, Monterey County, California, USA, is reported. The fungus caused a considerable host response resulting in numerous granulomas and follicular atresia. Based on morphologic characteristics, the fungus was probably a member of the class Oomycetes. This is the first report of an invasive ovarian mycosis in a marine fish.

Most fungal infections described from fishes produce lesions ranging from superficial invasion to severe ulceration of the integument (Roberts 1972, Wolke 1975, Neish \& Hughes 1980, Noga 1990). Occasionally, infections become systemic or penetrate muscle tissue and invade the viscera (Bootsma 1973, Nolard-Tintigner 1974, Hatai \& Egusa 1977, Miyazaki et al. 1977, Noga 1990). This paper is the first report of an invasive ovarian mycosis in a marine fish, the topsmelt Atherinops affinis (Ayres).

Materials and methods. The adult, female topsmelt was obtained from brood fish utilized in inducedspawning experiments (Middaugh et al. 1990) and was originally collected from waters at 33 ppt salinity and $16^{\circ} \mathrm{C}$ in Elkhorn Slough, Monterey County, California, USA. During laboratory spawning experiments, fish were maintained at $33 \%$ salinity and 18 to $21^{\circ} \mathrm{C}$ for ca $60 \mathrm{~d}$. Thereafter, the fish were fixed in $10 \%$ neutral buffered formalin; the ovaries were removed, dehydrated in a graded ethanol series, and embedded in paraffin. Sections were cut at $7 \mu \mathrm{m}$ and stained with Harris' hematoxylin and eosin for routine examination, and PAS-fast green to demonstrate fungi (Luna 1968).

Results. Grossly, the paired ovaries of the affected fish appeared darkly pigmented in comparison to ovaries of non-affected topsmelt. Gross internal examinations of normal ovaries revealed developing oogonia within the mesovarium and numerous spherical mature ova with little interfollicular tissue (Fig. 1). Affected

\footnotetext{
- Contribution No. 702, Gulf Breeze Environmental Research Laboratory
}

ovaries revealed similar mesovarial development; however, the mature ova were darkly pigmented and collapsed within an extensive matrix of interfollicular tissues (Fig. 2).

Histological examination of the affected ovaries revealed numerous PAS-positive, non-branching, aseptate fungal hyphae 12 to $20 \mu \mathrm{m}$ in diameter (Figs. 3 $\& 4)$. The fungus elicited a host response consisting of multifocal granulomas around hyphae (Figs. 3 \& 4). Granulomas consisted of macrophage aggregates occasionally surrounded by an outer layer of fibroblasts (Fig. 3). Some of the larger granulomas had eosinophilic necrotic debris, which resembled fungal hyphae, in their centers (Fig. 3). Numerous free macrophages were also observed in surrounding tissue. No penetration of oocytes by fungal hyphae was evident. In addition, interfollicular tissue consisted of large numbers of hypertrophied granulosa cells, involved in follicular atresia, containing an eosinophilic colloidlike substance (Figs. $3 \& 4$ ). Many oocytes showed folding of the zona pellucida into the ooplasm and corpora atretica were present throughout the ovaries (Fig. 4). The fungus was apparently restricted to the inside of the ovaries because no lesions were observed in the ovarian wall.

Discussion. Morphological characteristics of the fungus (i.e. large, aseptate, non-branching hyphae), tentatively place it in the class Oomycetes which contains fungal pathogens involved in most fish mycoses (Wolke 1975, Niesh \& Hughes 1980). Oomycetes include the Saprolegniales fungi (Alexopoulos 1962), which are opportunistic and considered secondary invaders to bacterial or viral diseases (Wolke 1975) or invade after some surface trauma (Richards \& Pickering 1978). There is also evidence that some oomycetes can act as primary pathogens (Vishniac \& Nigrelli 1957, Noga 1990), especially after fish have been overcrowded and/or stressed (Neish \& Hughes 1980).

The fungal hyphae caused a mycotic ovaritis which led to formation of numerous interfollicular 

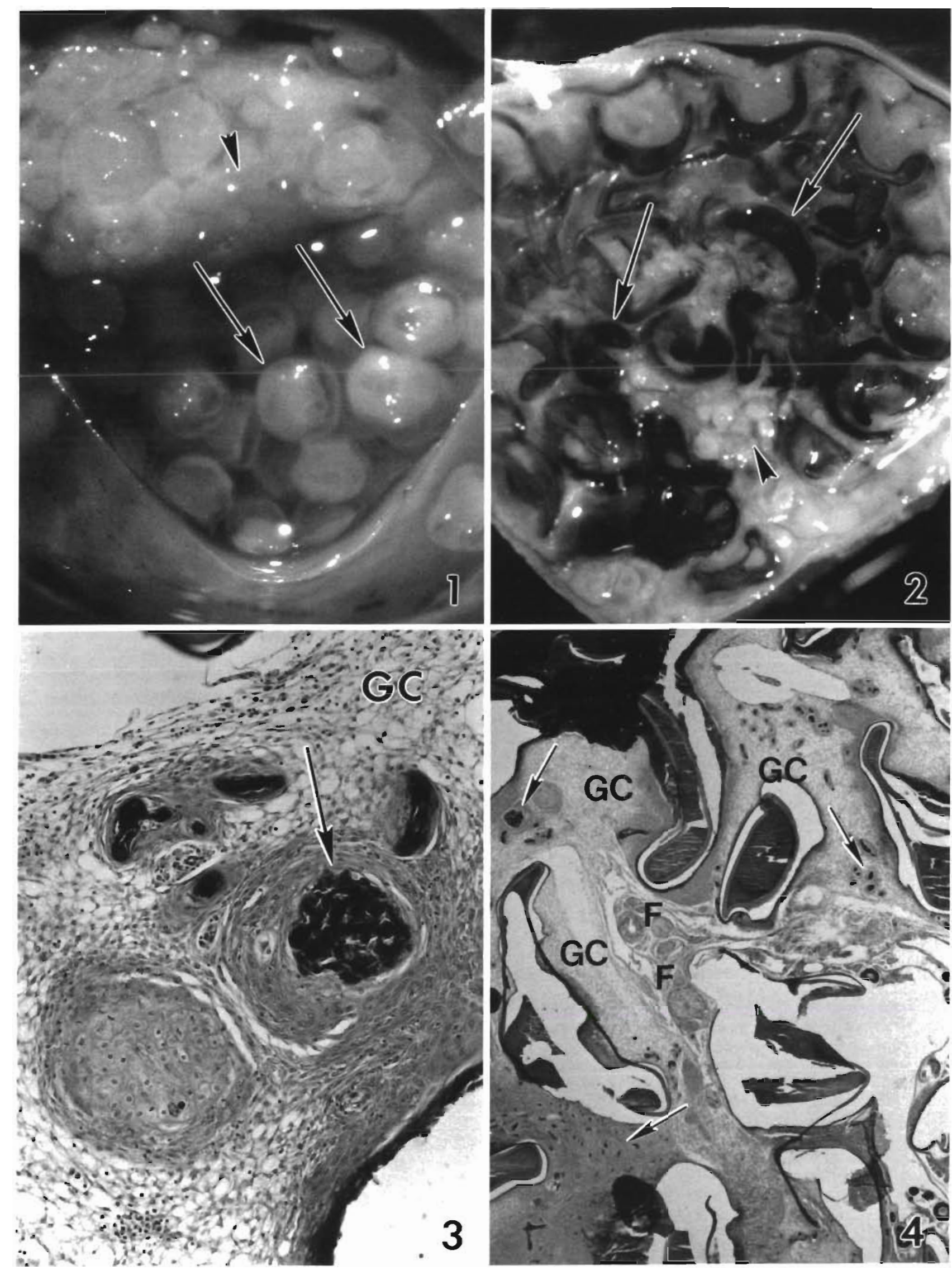

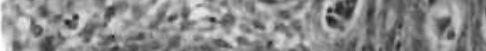

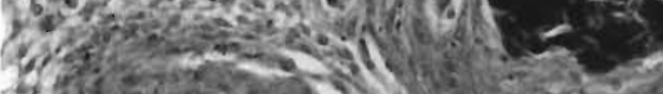

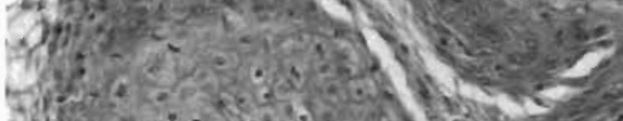

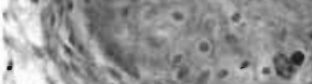

$4+2$. Whe

$5.0 .025 \%$. 20.42

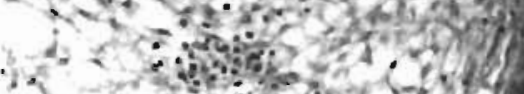

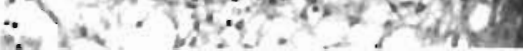
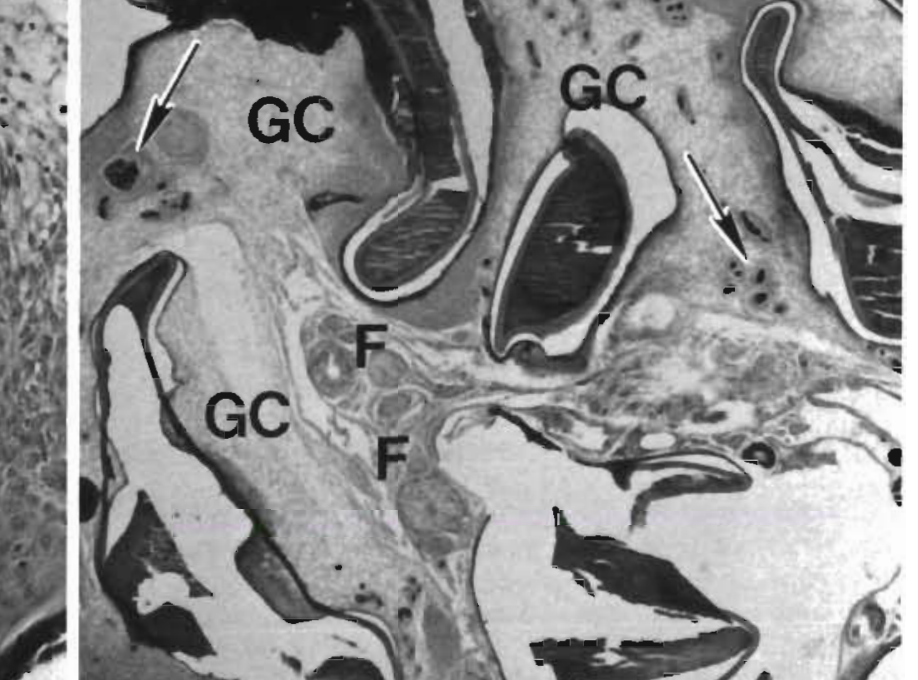

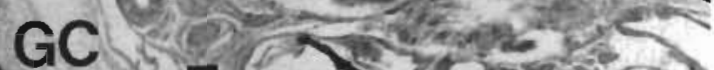

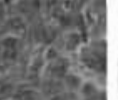


Fig. 1 to 4. Atherinops affinis. Fig. 1. Normal ovary from topsmelt, showing developing oogonia within mesovarium (arrow-head) and spherical mature ova (arrows). $(\times 10)$. Fig. 2. Ovarian mycosis showing darkened and compressed ova (arrows) within matrix of interstitial tissue. Note normal but reduced mesovarium containing developing oogonia (arrowhead). ( $\times 10)$. Fig. 3. High magnification showing small and well developed 'cystic' granulomas surrounding fungal hyphae. Note necrotic debris in center of one (arrow) and hypertrophied granulosa cells (GC). $(\times$ 195). Fig. 4. Low magnification showing numerous granulomas surrounding fungal hyphae (arrows), hypertrophied granulosa cells $(G C)$, collapsed eggs and atretic follicles $(F)$. $(\times 31.5)$

granulomas. The granulomas described are similar to those reported in Atlantic menhaden with ulcerative mycosis (Noga \& Dykstra 1986, Noga et al. 1988). Although granulomas did not have epithelioid-like cells, other similarities such as solid nodules in smaller granulomas and 'cystic' granulomas containing remnants of hyphae were apparent.

The appearance of corpora atretica and large numbers of hypertrophied granulosa cells is indicative of follicular atresia (Bretschneider \& Duyvene de Wit 1947). It is possible the mycosis interfered with normal egg development making it difficult for the fish to ovulate. Failure of ovulation leads to follicular atresia in fish (Leatherland \& Ferguson 1989).

The initial source of the fungal infection is uncertain. However, because it was apparently confined to the ovaries and no disruption of the ovarian wall or indication of involvement of other tissues or organs was noted, it is possible the fungus gained entrance to the ovaries through the genital opening. The fact that both ovaries were involved also supports this hypothesis. It is likely that a surface injury in the region of the genital pore may have provided the initial site of infection and that the fungus grew up the oviduct into the ovaries.

Oomycete infections in fish in salinities of $7 \%$ are rare (Wolke 1975). However, infections have been reported in menhaden in salinities as high as 13\% (Noga \& Dykstra 1986). Although the topsmelt was captured and held in water at $33 \%$, the fungus was probably not acquired at that high salinity. Atherinops affinis is a common fish in coastal bays but may enter fresh water to spawn (Hubbs 1918). The fungus infection was probably acquired when the fish was in freshwater. Once inside the ovaries, the fungus was insulated from higher salinities and able to continue growing.

\section{LITERATURE CITED}

Alexopoulos, C. J. (1962). The lower fungi. In: Introductory mycology. John Wiley \& Sons, Inc, New York, p. 67-134

Bootsma, R. (1973). Infections with Saprolegnia in pike culture (Esox lucius L.). Aquaculture 2: 385-394

Responsible Subject Editor: T. Evelyn, Nanaimo, B. C., Canada
Bretschneider, L. H., Duyvene de Wit J. (1947). Sexual endocrinology of non-mammalian vertebrates. Elsevier, Amsterdam

Hatai, K., Egusa, S. (1977). Studies on visceral mycosis of salmonid fry-II. Characteristics of fungi isolated from the abdominal cavity of amago salmon fry. Fish Pathol. 11. $187-193$

Hubbs, C. L. (1918). The fishes of the genus Atherinops, their variation, distribution, relationships, and history. Bull. Am. Mus. Natl. Hist. 38: 409-440

Leatherland, J. F., Ferguson, H. W. (1989). Endocrine and reproductive systems. In: Ferguson, H. W. (ed.) Systemic pathology of fish. Iowa State Univ. Press, Ames, p. 195-214

Luna, L. G. (1968). Manual of histologic staining methods of the Armed Forces Institute of Pathology, 3rd edn. McGraw-Hill Book Co., New York

Middaugh, D. P., Hemmer, M. J., Shenker, J. M., Takita, T. (1990). Laboratory culture of jacksmelt, Atherinopsis californiensis, and topsmelt, Atherinops affinis (Pisces: Atherinidae), with a description of larvae. Calif. Fish Game 76: $4-13$

Miyazaki, T., Kubota, S., Tashiro, F. (1977). Studies on visceral mycosis of salmonid fry - I. Histopathology. Fish Pathol. 11: 183-186

Neish, G. A., Hughes, G. C. (1980). Fungal diseases of fishes In: Snieszko, S. F., Axelrod, H. R. (eds.) Diseases of fishes, T F. H. Publications, Neptune, NJ, p. 8-47

Noga, E. J. (1990). A synopsis of mycotic diseases of marine fishes and invertebrates. In: Pathology in marine science. Academic Press, New York, p. 143-160

Noga, E. J., Dykstra, M. J. (1986). Oomycete fungi associated with ulcerative mycosis in menhaden, Brevoortia tyrannus (Latrobe). J. Fish Dis. 9: 47-53

Noga, E. J., Levine, J. F., Dykstra, M. J., Hawkins, J. H. (1988). Pathology of ulcerative mycosis in Atlantic menhaden Brevoortia tyrannus. Dis. aquat. Org. 4: 189-197

Nolard-Tintigner, N. (1974). Contribution a l'étude de la Saprolegniose des poissons en region tropical. Acad. R. Sci Outre-Mer, Cl. Sci. nat. med. (N.S.) 19: 1-58

Richards, R. H., Pickering, A. D. (1978). Frequency and distribution patterns of Saprolegina infection in wild and hatchery-reared brown trout Salmo trutta L. and char Salvenlinus alpinus (L.). J. Fish. Dis. 1: 69-82

Roberts, R. J. (1972). Ulcerative dermal necrosis (UDN) of salmon (Salmo salar L.). Symp. zool. Soc. Lond. 30: 53-81

Vishniac, H. S., Nigrelli, R. F. (1957). The ability of the Saprolegniaceae to parasitize platyfish. Zoologica 42: 131-134

Wolke, R. E. (1975). Pathology of bacterial and fungal diseases affecting fish. In: Ribelin, W. E., Migaki, G. (eds.) The pathology of fishes. Univ. of Wisconsin Press, Madison, p. 33-116

Manuscript first received: June 12, 1990

Revised version accepted: March 5, 1991 